\title{
Germination of Range Plant Seeds after Long Periods of Uncontrolled Storage
}

$\begin{array}{lcc}\text { Characteristics } & \text { Twin Falls } & \text { LaGrande } \\ \begin{array}{c}\text { Elevation (ft) } \\ \text { Average annual } \\ \text { precipitation }\end{array} & 3,750 & 2,760 \\ \begin{array}{l}\text { (inches) } \\ \text { Average relative } \\ \text { humidity (\%) }\end{array} & & 20.7 \\ \quad \text { January } & 75 & 70 \\ \quad \text { July } & 35 & 28 \\ \begin{array}{c}\text { Average temper- } \\ \text { atures }\left({ }^{\circ} \mathrm{F}\right)\end{array} & & \\ \quad \begin{array}{l}\text { January } \\ \text { July }\end{array} & 27 & 30 \\ \begin{array}{c}\text { Temperature } \\ \text { extremes }\left({ }^{\circ} \mathrm{F}\right)\end{array} & 72 & 71 \\ \quad \text { Maximum } & 105 & 109 \\ \quad \text { Minimum } & -26 & -22\end{array}$

\section{A. C. HULL, JR.}

Highlight: One hundred sixty-six lots of seed representing 60 species were stored from 14 to 41 years in unheated sheds. After 14 years storage only 36 of the 102 lots of grass produced seedlings. Of the 68 lots stored for 20 years, only 16 emerged. After 27 years of storage no grass seeds were viable. All 24 lots of legume seed produced seedlings after 14 years storage. Fifteen lots stored 20 years or more were all viable. Of the 21 lots of forb seed stored from 23 to 41 years only Erodium cicutarium produced seedlings. Stored for 37 years, this was the oldest seed to germinate. None of five lots of shrub seed stored 20 years were viable.

Some seeds remain viable for several hundred years, while others have a short life span. Seeds with good longevity are usually heavy, with hard and impervious coats. Seeds with permeable seed coats, such as many cereals and grasses, seldom retain their viability more than a few years. Longevity of most seeds is increased by storage at low temperatures, low moisture content and humidity, and absence of oxygen (Barton, 1953, 1961; Crocker, 1945).

Mirov and Kraebel (1939) recommended storing seeds of native western plants in well-ventilated rooms at ordinary temperatures. Tiedemann and Pond (1967) lested seeds of 12 southern Arizona range grasses that had been stored without humidity or temperature control for 22 to 28 years. Four of the 12 species were viable and germinated from 3 to $34 \%$. Blake (1935) found that seeds of prairie plants stored at room tem-

The author is range scientist, Plant Science Research Division, Agricultural Research Service, U. S. Department of Agriculture, Logan, Utah.

The research is a result of cooperative investigations of Plant Science Research Division, Agr. Res. Serv., U. S. Dep. Agr.; U. S. Forest Service, U. S. Dep. Agr.; and Utah Agricultural Experiment Station. (Utah Agricultural Experiment Station Journal Paper 1230.)

The author thanks those who supplied information, assisted with the laboratory and greenhouse work, or made helpful comments on the manuscript. Special thanks are due to Relda Felix, Theron Hansen, Rudolph Niederhauser, and Bernard Thurston who did most of the seed counting and weighing and greenhouse germination.

Man uscript received February 22, 1972. peratures in Nebraska had little viability at the end of $5 \frac{1}{2}$ years.

Windle et al.(1966) state that the cool, dry climatic conditions in southern Idaho are ideal for seed storage and that most grass seeds stored here will maintain high viability for several years. Hafenrichter et al. (1965) stored seeds of 21 grasses in unheated warehouses at four locations in the West. At the end of 14 years eight grasses germinated $70 \%$ at Aberdeen, Idaho, but no species germinated $70 \%$ at the other three locations. They listed the Aberdeen climate as cool and dry compared to that in the other locations.

The seeds of the range plants and some weeds used in this study were obtained for experimental and large-scale range seedlings or for beet-leafhopper studies. Seeds were stored in unheated sheds, the usual procedure for seed storage in the West. The seeds were tested during 196971 to determine their viability after storage for 14 to 41 years.

\section{Description of the Storage Areas}

In 1969 , we moved over 250 lots of seed from Twin Falls, Idaho, to Logan, Utah. The older seeds had been stored continuously at Twin Falls. About half the lots were stored at LaGrande, Ore., until 1960 and then moved to Twin Falls. Storage at both locations was in wooden frame sheds that had tin sides and roofs. Seeds were kept in paper or cloth sacks inside wooden, mouse-proof lockers. Neither seed containers nor lockers were air-tight. Some characteristics of the two storage areas follow:
Summer air temperatures are several degrees higher inside the sheds than outside. For example, during August 1971 at Twin Falls, the extreme maximum and minimum inside were 101 and $50^{\circ} \mathrm{F}$, compared to 94 and $40^{\circ} \mathrm{F}$, outside.

\section{Procedures}

All seeds which had been stored at least 14 years were tested for viability. Recent collections of 10 species were used as checks. There were 166 lots, representing 60 species.

We determined emergence by planting 50 seeds 0.2 inches deep in moist sand in a greenhouse where night and day temperatures usually ranged between 52 and $70^{\circ} \mathrm{F}$ and 75 and $90^{\circ} \mathrm{F}$, respectively. Temperature ranges during the study did not appear to influence seedling emergence. Starting two days after seeding and continuing for 30 days, emerged seedlings were counted and removed daily. For 31 to 42 days seedlings were counted every 3 days, and from 43 to 60 days, every 6 days. Treatments were replicated four times, and replications were run consecutively during the winters of 196971. Many species had been tested for germination shortly after collection. These germination percentages are listed with the present tests.

\section{Results and Discussion}

Seed lots with the early germination and percent seedling emergence in 1969 71 are shown in Table 1 . Seed lots with no emerged seedlings in 1969-71 are listed below. (The numbers in parentheses indicate the number of seed lots for that species. An $a$ indicates storage at LaGrande until 1960):

\section{Species}

Years storage

\section{Grasses}

Agropyron cristatum

A. dasystachyum ${ }^{\mathrm{a}}(3)$

A. desertorum (3)

A. elongatum ${ }^{\mathrm{a}}$

A. inerme $e^{\mathrm{a}}$

A. intermedium ${ }^{\mathrm{a}}$ (2)
18 to 26

19 to 24

20

22

22 to 23 
A. intermedium Amur ${ }^{\mathrm{a}}$

A. repens $^{\mathrm{a}}$ (3)

A. sibiricum ${ }^{\mathrm{a}}$ (3)

A. smithii ${ }^{\mathrm{a}}$ (3)

A. spicatum $^{\text {a }}$ (3)

A. subsecundum ${ }^{\text {a }}$ (2)

A. trachycaulum ${ }^{\text {a }}$ (3)

Bromus carinatus (3)

B. erectus ${ }^{\mathrm{a}}$

B. inermis ${ }^{\text {a }}$ (2)

B. tectorum ${ }^{\mathrm{a}}(9)$

B. tomentellus ${ }^{\mathrm{a}}$

Elymus glaucus ${ }^{\mathrm{a}}$ (4)

E. junceus ${ }^{\mathrm{a}}(2)$

E. salina

E. triticoides $^{\mathrm{a}}$

Festuca arundinacea ${ }^{\mathrm{a}}$ (2)

F. rubra a (3)

Orysopsis hymenoides

Phleum phleoides ${ }^{\mathbf{a}}$

Poa bulbosa

$P$. secunda (5)

Forbs

Descurainia sp. $(10$

Salsola kali tenuifolia (5)
27 to 41

22 to 23

20 to 24

19 to 23

16 to 18

22

19 to 20

28 to 42

19

18 to 21

19 to 25

30

23

21 to 24

18 to 20

41

25

36

28 to 39

23 to 41

38 to 41
39 to 41

mbrium altissimum (5)

\section{0}

Artemisia tridentata

40

Cerocarpus ledifolius ${ }^{\mathbf{a}}$

Chrysothamnus nauseosus

23

40

C. viscidiflorus

40

After 14 years storage, 36 of the 102 lots of grass seed produced seedlings. Of the 68 lots stored 20 years only 16 emerged. The two best at 20 years were: Agrostis alba (50\%) and Oryzopsis hymenoides (38\%). Twenty-one seed lots of eight grasses were stored 27 years or more and all failed to emerge.

Seeds with hard seed coats, such as the legumes, retained their viability longer than soft-coated seeds, such as many grasses. All 24 lots of legume seed produced seedlings after 14-years storage. Fifteen lots stored 20 years or more were all viable when tested. The best viability was Trifolium repens, $73 \%$ after 25 years, and Lotus corniculatus, $65 \%$ after 28 years. No legume seeds were stored beyond 28 years.

After 23- to 41-years storage only one of the 21 forb seed lots emerged. Seeds of Erodium cicutarium germinated 5.5\% after 37-years storage. This was the oldest seed to germinate. After 14-years storage two of the seven lots of shrub seed were viable. After 20-years storage, none of the five lots were viable.

Speed of germination is a species characteristic. Within each species, however, the younger seeds emerged more rapidly than did the older seeds. The most rapidly emerging seedlings were the annuals, notably: Salsola kali tenuifolia, Sisymbrium altissimum, Bromus tectorum, and $B$. arvensis. Close behind were some

Table 1. Age (years) and emergence (\%) of range plant seeds stored at Twin Falls, Idaho and LaGrande, Oregon for long periods in uncontrolled environments.

\begin{tabular}{|c|c|c|c|c|c|c|c|}
\hline \multirow[b]{2}{*}{ Species } & \multirow[b]{2}{*}{ Years storage } & \multicolumn{2}{|c|}{ Emergence } & \multirow[b]{2}{*}{ Species } & \multirow[b]{2}{*}{ Years storage } & \multicolumn{2}{|c|}{ Emergence } \\
\hline & & Year grown & $1969-71$ & & & Year grown & $1969-71$ \\
\hline \multicolumn{8}{|l|}{ Grasses } \\
\hline \multirow[t]{4}{*}{ Agropyron desertorum } & $19^{a}$ & 85 & 1.5 & $P$. longifolia & $20^{\mathrm{a}}$ & & 1.0 \\
\hline & 17 & 86 & 3.5 & & & & \\
\hline & 14 & & 11 & Legumes & & & \\
\hline & 2 & 96 & 83 & Astragalus cicer & $22^{\mathrm{a}}$ & 91 & 43 \\
\hline \multirow[t]{3}{*}{ A. elongatum } & 19 & 85 & 3.5 & & $19^{\mathrm{a}}$ & 92 & 54 \\
\hline & $18^{a}$ & 83 & 1.0 & & $18^{\mathrm{a}}$ & & 55 \\
\hline & $18^{a}$ & & 1.0 & A. falcatus & $23^{a}$ & 98 & 10 \\
\hline \multirow[t]{3}{*}{ A. intermedium } & $26^{a}$ & 80 & 2.0 & R. Juscation & $23^{a}$ & 97 & 8.0 \\
\hline & $22^{a}$ & 84 & 2.5 & & $22^{a}$ & 92 & 3.5 \\
\hline & $2^{a}$ & 95 & 93 & & $21^{\mathrm{a}}$ & 93 & 1.5 \\
\hline \multirow[t]{2}{*}{ A. intermedium Amur } & $21^{\mathrm{a}}$ & & 0.5 & & 17 & & 3.5 \\
\hline & $18^{\mathrm{a}}$ & & 9.0 & Lathyrus sylvestris & 17 & & 21 \\
\hline \multirow[t]{2}{*}{ A. sibiricum } & $18^{\mathrm{a}}$ & & 1.0 & Lotus corniculatus & $28^{a}$ & & 3.0 \\
\hline & 3 & & 94 & & 28 & & 65 \\
\hline A. spicatum & 4 & & 80 & Medicago sativa & $24^{\mathrm{a}}$ & 83 & 26 \\
\hline \multirow[t]{3}{*}{ A. trichophorum } & $20^{a}$ & & 4.5 & 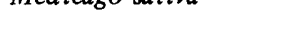 & 20 & & 35 \\
\hline & $20^{\mathrm{a}}$ & 79 & 4.0 & & 19 & 91 & 46 \\
\hline & $18^{\mathrm{a}}$ & & 15 & & $19^{\mathrm{a}}$ & 85 & 54 \\
\hline Agrostis alba & 20 & 90 & 50 & & $19^{a}$ & 98 & 81 \\
\hline A. tenuis oregonensis & $25^{\mathrm{a}}$ & 82 & 7.0 & & 2 & & 86 \\
\hline \multirow[t]{2}{*}{ Alopecurus arundinaceus } & $20^{\mathrm{a}}$ & & 21 & & & & \\
\hline & 17 & & 8.5 & Melilotus alba & 19 & 91 & 30 \\
\hline $\begin{array}{l}\text { A. pratensis } \\
\text { Arrhenatherum elatius }\end{array}$ & $19^{\mathrm{a}}$ & & 15 & Trifolium fragiferum & $26^{\mathrm{a}}$ & 80 & 30 \\
\hline \multirow{2}{*}{$\begin{array}{l}\text { Arrhenatherum elatius } \\
\text { Bromus arvensis }\end{array}$} & $23^{a}$ & 90 & 4.5 & $T$.repens & $25^{\mathrm{a}}$ & 88 & 73 \\
\hline & $17^{\mathrm{a}}$ & & 65 & $T$. subterraneum & $25^{\mathrm{a}}$ & 79 & 29 \\
\hline B. erectus & $\begin{array}{l}21^{\mathrm{a}} \\
18^{\mathrm{a}}\end{array}$ & & $\begin{array}{l}2.0 \\
4.5\end{array}$ & Vicia tenuifolia & $22^{\mathrm{a}}$ & 77 & 40 \\
\hline \multirow{2}{*}{ B. inermis } & $19^{a}$ & & $\begin{array}{l}4.0 \\
1.5\end{array}$ & & $20^{\mathrm{a}}$ & & 21 \\
\hline & 3 & 88 & 87 & & $20^{\mathrm{a}}$ & & 40 \\
\hline \multirow[t]{3}{*}{ B. tectorum } & 10 & 100 & 100 & & $19^{\mathrm{a}}$ & & 25 \\
\hline & 9 & & 98 & & & & \\
\hline & 1 & & 100 & Forbs & & & \\
\hline \multirow[t]{2}{*}{ Dactylis glomerata } & $20^{\mathrm{a}}$ & & 29 & Erodium cicutarium & 37 & & 5.5 \\
\hline & $18^{a}$ & & 8.0 & Salsola kali tenuifolia & 1 & & 67 \\
\hline \multirow{4}{*}{$\begin{array}{l}\text { Festuca arundinacea } \\
\text { Hordeum bulbosum } \\
\text { Oryzopsis hymenoides } \\
\text { Phleum phleoides }\end{array}$} & $19^{\mathrm{a}}$ & 93 & 4.5 & Sisymbrium altissimum & 1 & & 93 \\
\hline & 17 & & 1.0 & & & & \\
\hline & 26 & & 38 & & & & \\
\hline & $19^{a}$ & 91 & 24 & Shrubs & & & \\
\hline \multirow{5}{*}{$\begin{array}{l}\text { P. pratense } \\
\text { Poa ampla }\end{array}$} & $18^{\mathrm{a}}$ & & 7.0 & Artemisia tridentata & 2 & & 53 \\
\hline & $22^{\mathrm{a}}$ & 85 & 6.0 & Atriplex canescens & 19 & & 3.5 \\
\hline & $21^{\mathrm{a}}$ & 82 & 8.5 & Purshia tridentata & 14 & & 45 \\
\hline & $20^{\mathrm{a}}$ & 85 & 5.5 & Stored at LaGrande un & & & \\
\hline & $19^{a}$ & & 15 & & & & \\
\hline
\end{tabular}


legumes: Medicago sativa, Melilotus alba, and the Trifoliums. The slowest seedlings to emerge were those from large, thickcoated seeds, such as Lathyrus sylvestris, Vicia tenuifolia, and Purshia tridentata.

Each lot of 50 seeds was weighed to the nearest $.01 \mathrm{~g}$. Within or between species, seed size could not be correlated with seed longevity.

\section{Conclusions}

Even under the cool, dry, and relatively favorable storage conditions in this study, the percentage and speed of seedling emergence decreased with age. Seeds of grasses, legumes, forbs, and shrubs stored for range seeding should be checked for germination. The seeding rates can then be adjusted to compensate for low viability.

\section{Literature Cited}

Barton, Lela V. 1953. Seed storage and viability. Contrib. Boyce Thompson Inst. 17:87-103.

Barton, Lela V. 1961. Seed preservation and longevity. Interscience Publ., Inc. New York. $216 \mathrm{p}$.

Blake, Abigail Kincaid. 1935. Viability and germination of seeds and early life history of prairie plants. Ecol. Monogr. 5:405-460.
Crocker, William. 1945. Longevity of seeds. J. New York Bot. Garden. 46:26-36.

Hafenrichter, A. L., R. B. Foster, and J. L. Schwendiman. 1965. Effect of storage at four locations in the West on longevity of forage seeds. Agron. J. 57:143-147.

Mirov, N. T., and Charles J. Kraebel. 1939. Collecting and handling seeds of wild plants. Civilian Conserv. Crops Forest. Pub. 42 p.

Tiedemann, Arthur R., and Floyd W. Pond. 1967. Viability of grass seed after long periods of uncontrolled storage. J. Range Manage. 20:261-262.

Windle, Leaford, C., Hugh C. McKay, and Ronald B. Foster, 1966. Grass seed production on Southern Idaho dryland farms. Idaho Agr. Exp. Sta. Bull. 473. 11 p. 